\title{
From Joseph to Moses: The Narratives of Exodus 1-2
}

\author{
Joel S. Baden \\ Yale University \\ joel.baden@yale.edu
}

\begin{abstract}
In this paper it is argued that the canonical text of Exodus 1-2 is a compilation of three originally independent narratives belonging to the pentateuchal sources J, E, and P. The text of Exodus 1-2 is divided source-critically, and each individual narrative analyzed on its own terms. Each of these stories contains specific narrative claims that are distinct from that of the canonical text as a whole, and each represents a continuation of the patriarchal narratives into the Exodus account.
\end{abstract}

\section{Keywords}

Exodus, Pentateuch, documentary hypothesis

The canonical text of Exodus 1-2 contains a number of famous narrative elements: the dramatic increase of the Israelite population; the oppression of the Egyptians; the edict of Pharaoh demanding the death of all newborn Israelite boys; the story of Moses' birth and adoption by Pharaoh's daughter; and the story of Moses killing the Egyptian taskmaster and fleeing to Midian. Given the stature of each of these elements in the reception history of the text, it is difficult to imagine the beginning of the Exodus story without them. Yet the text also contains a number of narrative difficulties, which have led scholars to the conclusion that it is composite-although there is little consensus on precisely how the passage is to be divided. When the text is analyzed sourcecritically, it is evident that not all the elements listed above belong to all of the narratives. Indeed there are three narratives of the period from Joseph to Moses, each containing distinctive claims about what happened, when, how, and why; none of the narratives is particularly close to the canonical story, and some are in fact radically different. This paper will analyze Exodus 1-2 sourcecritically, and examine in detail the individual narratives that make up the final form of the text. 


\section{Source Division}

In the first chapter of Exodus, there are three separate notices of the increase of the Israelites. The first, in Exod 1:7, comes before the Israelites have been oppressed: "The Israelites were fertile and prolific; they multiplied and increased very greatly, so that the land was filled with them." Yet in 1:10, the new king of Egypt decides to impose forced labor on the Israelites precisely to prevent them from increasing: "Let us deal shrewdly with them, so that they may not increase." This instruction, in light of 1:7, would appear to come too late. But in 1:12, we are told that "the more they were oppressed, the more they increased and spread out." Thus, it seems, Pharaoh's intentions in 1:10 were not too late-though they were ineffective. Again, in 1:15-16, Pharaoh institutes a policy intended to prevent the Israelites from increasing, now doubly late: the Hebrew midwives are to kill all newborn Israelite boys. Like the policy of imposing labor on the Israelites, these instructions too presume that the Israelites have not yet increased, a presumption which is given added weight by the fact that two midwives are evidently sufficient to care for the entire Israelite populace (1:15). And for the second time, Pharaoh's policy fails: "and the people multiplied and increased greatly" (1:20)—this now for the third time.

There are also two separate notices of the manner by which Pharaoh imposed labor on the Israelites. The first, as noted above, is intended to prevent the Israelites from increasing: "Let us deal shrewdly with them, so that they may not increase" $(1: 10)$. The work they are put to is specifically described as the construction of two new cities: "So they set taskmasters over them to oppress them with forced labor, and they built garrison cities for Pharaoh: Pithom and Raamses" (1:11). The second notice comes after the Israelites have already increased-twice-and is described differently: "The Egyptians ruthlessly imposed labor upon the Israelites; they made their lives bitter with harsh labor at mortar and bricks and with all sorts of tasks in the field-all the labor that they ruthlessly imposed on them" (1:13-14). The Israelites are here not simply building cities - in fact, it is not clear that they are building new cities at allbut are rather doing both urban construction as well as agricultural labor.

The chapter thus contains narrative contradictions and doublets, even triplets, that prevent a smooth reading of the text. The solution to these problems, as most commentators have concluded, is to recognize that the chapter is composite. ${ }^{1}$ The first five verses, which list Jacob's sons and give the tally of seventy

1) Those scholars who argue for compositional unity in these chapters also tend, not surprisingly, to ignore these narrative difficulties in favor of structural or thematic considerations; cf., e.g., J. S. Ackerman, "The Literary Context of the Moses Birth Story (Exodus 1-2)", in Kenneth 
as the total number of Jacob's household in Egypt, are widely acknowledged to belong to P. They are an abbreviated version of the more extensive enumeration provided by $\mathrm{P}$ in Gen 46:8-27. Exod 1:6, however, interrupts the natural progression from 1:5 to 1:7. The latter verse begins with a disjunctive clause, and is to be understood as adversative: "But the Israelites were fertile and prolific, etc." This is perfectly sensible as the immediate continuation of 1:5: Jacob's family was only seventy people when they came to Egypt (1:5), but they were fertile and multiplied greatly (1:7). It is far less so as the continuation of 1:6: Joseph and his generation died (1:6), but the Israelites were fertile (1:7). Moreover, just as 1:1-5 are a recapitulation of previously given information in P, so too 1:7 repeats P's description of the increase of the Israelites from Gen 47:27b-which took place, obviously, before the death of Joseph and his generation. Thus Exod 1:6 cannot belong to P, while 1:1-5, 7 do. ${ }^{2}$

R. R. Gros Louis, et al. (eds.), Literary Interpretations of Biblical Narratives (Nashville, 1974), pp. 74-119; D. W. Wicke, “The Literary Structure of Exodus 1:2-2:10", JSOT 24 (1982), pp. 99-107; B. Weber, “'Jede Tochter aber sollt ihr am Leben lassen!'-Beobachtungen zu Ex 1,15-2,10 und seinem Kontext aus literaturewissenschaftlicher Perspektive," BN 55 (1990), pp. 47-76 (esp. 65-71); J. Siebert-Hommes, "Die Geburtsgeschichte des Mose innerhalb des Erzählzusammenhangs von Exodus i und ii", VT 42 (1992), pp. 398-404; G. Fischer, "Exodus 1-15-Eine Erzählung", in Marc Vervenne (ed.), Studies in the Book of Exodus (BETL 126; Leuven, 1996), pp. 149-178. On the issues surrounding the use of modern literary readings to determine the compositional history of a text, cf. J. S. Baden, "The Tower of Babel: A Case Study in the Competing Methods of Historical and Modern Literary Criticism”, JBL 128 (2009), pp. 209-224.

2) Cf. T. Nöldeke, Untersuchungen zur Kritik des Alten Testament (Kiel, 1869), p. 35; J. Wellhausen, Die Composition des Hexateuchs und der historischen Bücher des Alten Testaments (Berlin, 1963), pp. 61-62; B. W. Bacon, The Triple Tradition of the Exodus (Hartford, 1894), pp. 6-7; W. E. Addis, The Documents of the Hexateuch (2 vols.; London, 1892-1898), vol. 2, p. 234; A. Dillmann, Die Bücher Exodus und Leviticus (3rd ed.; Kurzgefasstes exegetisches Handbuch zum Alten Testament 12; Leipzig, 1897), p. 1; J. E. Carpenter and G. Harford-Battersby, The Hexateuch According to the Revised Version (2 vols.; New York, 1900), vol 2, pp. 79-80; H. Holzinger, Exodus (KHC 2; Tübingen, 1900), p. 1; B. Baentsch, Exodus-Leviticus-Numeri übersetzt und erklärt (HKAT I/2; Göttingen, 1903), p. 1; E. Meyer, Die Israeliten und ihre Nachbarstämme: Alttestamentlich Untersuchungen (Halle, 1906), p. 41; R. Smend, Der Erzählung des Hexateuch auf ihre Quellen untersucht (Berlin, 1912), p. 120; H. Gressmann, Mose und seine Zeit: Ein Kommentar zu den Mose-Sagen (FRLANT 1; Göttingen, 1913), p. 1 n. 1; A. H. McNeile, The Book of Exodus (2nd ed.; WC; London, 1917), p. 2; S. R. Driver, The Book of Exodus (CBC; Cambridge, 1918), pp. 1-2; E. S. Brightman, The Sources of the Hexateuch (New York, 1918), p. 231; W. Rudolph, Der "Elohist" von Exodus bis Josua (BZAW 68; Berlin, 1938), p. 1; C. A. Simpson, The Early Traditions of Israel: A Critical Analysis of the Pre-Deuteronomic Narrative of the Hexateuch (Oxford, 1948), p. 158; W. H. Schmidt, Exodus (BKAT II/1; Neukirchen, 1988), pp. 9-12; E. Blum, Studien zur Komposition des Pentateuch (BZAW 189; Berlin, 1990), pp. 239240; N. Lohfink, "The Priestly Narrative and History", in idem, Theology of the Pentateuch: Themes of the Priestly Narrative and Deuteronomy (Minneapolis, 1994), pp. 136-72 (145 n. 29). 
As a support for this analysis, we may note the variety of distinctly P stylistic features in Exod 1:1-5, 7. In 1:1, the repetition of the root $b$-w-' in the participle and the perfect is paralleled directly in Gen 7:16, and conforms to typical priestly style. ${ }^{3}$ In Exod 1:5, the phrase kol-nepes is unique to P (cf. Gen $1: 21 ; 9: 10,12,15,16 ; 46: 15,22,25,26$; Lev 7:27; 17:12; 24:17; Num 31:35); the phrase m'od m'od, with or without preposition, is also uniquely priestly (cf. Gen 7:19; 17:2, 6, 20; 30:43; Num 14:7). In Exod 1:7, the terms used to describe the increase of the Israelites, pār $\hat{u}$ wayyišr ${ }^{2} \hat{u}_{\hat{u}}$ wayyirb $\hat{u} .$. wattimmāle häāres, are immediately familiar (cf. Gen 1:22, 28; 8:17; 9:1, 7; $17: 20 ; 28: 3 ; 35: 11 ; 47: 27 ; 48: 4$; Lev 26:9). It is possible, though neither definitive nor necessary, that, as many scholars have surmised, wayya'asmî in Exod 1:7 is a secondary expansion on the basis of Exod 1:9, as the word does not appear in any of the aforementioned parallel $\mathrm{P}$ texts (wayyirb $\hat{u}$ is clearly original to $\mathrm{P}$, against those scholars who claim both words, wayyirb $\hat{u}$ wayya 'asm $\hat{u}$, to be secondary); it cannot, however, be an original fragment of a non-priestly source, as it is completely disconnected from any continuous narrative.

Exod 1:6 is, for its part, the direct continuation of the last J verse of Genesis 50 ; it is, in fact, the second half of a single sentence: "Joseph lived 110 years [Gen 50:22b] and Joseph died, and all his brothers, and all that generation [Exod 1:6]." It continues directly in 1:8: "A new king arose over Egypt who did not know Joseph." These two successive sentences therefore mark the change in generation among both the Israelites and the Egyptians. ${ }^{5}$ The J story in 1:8-12 is an indivisible unity. ${ }^{6}$ The word beginning $1: 9$, wayyomer, "he

3) Cf. M. Paran, Forms of the Priestly Style in the Pentateuch: Patterns, Linguistic Usages, Syntactic Structures ([in Hebrew] Jerusalem, 1989), p. 67.

4) In Genesis 50, the J narrative comprises 50:1-11, 14-22; E comprises 50:23-26; and P comprises only 50:12-13. The notice of Joseph's death in 50:26 (E) is therefore a parallel to the combined text of 50:22 and Exod 1:6 (J). For the source attribution of Genesis 50, and the Joseph story as a whole, I follow the analysis of B. Schwartz, "J and E in the Joseph Saga," paper presented in the Pentateuch Section of the SBL Annual Meeting, 2009.

5) The continuity of these verses and their role in demarcating a new epoch in Israelite history have been noted at length by Th. C. Vriezen, "Exodusstudien. Exodus I.", VT 17 (1967), pp. 334-53 (334-44), though the connection he draws between Exod 1:6, 8 and Judg 2:8-10 was already noted by Nöldeke, Untersuchungen, p. 35. The view that these verses serve to "distance the events of the Joseph story from that which follows" (K. Schmid, Genesis and the Moses Story: Israel's Dual Origins in the Hebrew Bible [Siphrut 3; Winona Lake, 2010], p. 34) seems somewhat backward; surely the direct reference to the death of Joseph serves rather to connect the generations of the patriarchs with that of the Exodus, rather than the reverse.

6) Note the regular use of the singular to refer to the Israelites (following Pharaoh's reference to them as 'am b’nê yiśräêel in 1:8); cf. M. Greenberg, Understanding Exodus (New York, 1969), p. 20. 
said," requires an antecedent, which is provided by "a new king" in 1:8. The speech beginning in 1:9 continues unbroken into $1: 10$, while $1: 11$ records the fulfillment of Pharaoh's plans in the preceding speech. The description of the increase of the Israelites in 1:12 begins with the explicit verbal undermining

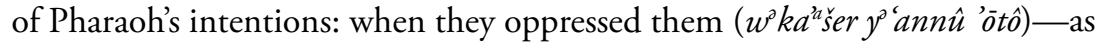
it says they did in 1:11 (l'ma'an 'annōtô)_-yet they increased (kèn yirbe $\left.e^{b}\right)$-as Pharaoh feared they would in 1:10 (pen-yirbe $\left.e^{h}\right){ }^{7}$ Two other narrative elements support the attribution of this story to J. The new Pharaoh's ignorance of Joseph may have in mind not only Joseph's service to Egypt, but also the previous king's promise to care for Joseph's family, related by J in Gen 45:18: "I will give you the best of the land of Egypt and you shall live off the fat of the land." 8 And when the Israelites increase in Exod 1:12, they are said to spread out (yiprōs); this reflects the uniquely J concept that the Israelites were living not intermingled with the Egyptians, but only in one region of Egypt, that of Goshen (cf. Gen 45:10; 47:4; Exod 8:18; 9:26). ${ }^{9}$ Thus in Exod 1:6, 8-12 we have a coherent story, identifiable on narrative grounds as being from $\mathrm{J} .{ }^{10}$ This identification is supported by the presence of typical J stylistic features. The

7) Cf. U. Cassuto, A Commentary on the Book of Exodus (Jerusalem, 1997), p. 11. Pharaoh's fear in Exod 1:10 that the Israelites may increase presents a significant problem for the theory that 1:8-12 presuppose the P text of 1:7 and are therefore a later composition (Schmid, Genesis, pp. 62-65 and passim; similarly J. C. Gertz, Tradition und Redaktion in der Exoduserzählung: Untersuchungen zur Endredaktion des Pentateuch (FRLANT 186; Göttingen, 2000), pp. 365371, who attributes 1:8-10 to his Endredaktion). Pharaoh's fear does not presuppose the increase of the Israelites in 1:7, it directly contradicts it. Against Schmid and Gertz's view that 1:9 depends on 1:7, see D. M. Carr, "What is Required to Identify Pre-Priestly Narrative Connections between Genesis and Exodus? Some General Reflections and Specific Cases," in T. B. Dozeman and K. Schmid (eds.), A Farewell to the Yahwist? The Composition of the Pentateuch in Recent European Interpretation (SBLSymS 34; Atlanta, 2006), pp. 159-80 (172-73).

8) We may also note the connection between the Pharaoh of Exod 1:8, who does not know Joseph, and the Pharaoh of Exod 5:2 (J), who does not know Yahweh (cf. Ackerman, "Literary Context," p. 79).

9) The verb $p$ - $r$-s is used similarly elsewhere in J (Gen 28:14; 30:30). Whereas in J the Israelites are confined to the region of Goshen, as Exod 1:12 seems to recognize, when P says "the land was filled with them" in 1:7 it conforms to the picture in Exod 12:12-13, P's instructions to the Israelites about putting the blood of the passover lamb on their doorposts; this latter passage assumes that the Israelites and the Egyptians are living intermingled, such that a visual distinction between their houses would have to be made.

10) Cf. Bacon, Triple Tradition, p. 8; Dillmann, Exodus, pp. 3-13; Carpenter and HarfordBattersby, Hexateuch, vol. 2, pp. 80-81; Holzinger, Exodus, p. 1; McNeile, Exodus, pp. 3-4; Driver, Exodus, pp. 2-5; Brightman, Sources, p. 79; Schmidt, Exodus, pp. 13-15; W. H. C. Propp, Exodus 1-18 (AB 2; New York, 1999), p. 126; A. Graupner, Der Elohist: Gegenwart und Wirksamkeit des transzendenten Gottes in der Geschichte (WMANT 97; Neukirchen-Vluyn, 2002), p. 45. 
phrase kol-'ẹāyw in Exod 1:6 is attested five times elsewhere in J (Gen 16:12; $25: 18 ; 27: 37 ; 37: 4 ; 45: 15$ ), and once in D (Deut 18:7). The use in Exod 1:10 of $h \bar{a} b \bar{a}^{h}$ as an exhortative particle preceding a cohortative is unique to J (cf. Gen 11:3, 4, 7; 38:16). Pharaoh's announcement that the Israelites are 'àsîm (Exod 1:9) looks to be the fulfillment of Yahweh's words in Gen 18:18 (J).

The discrepancy between the two descriptions of the labor imposed on the Israelites in 1:11 and 1:13-14 has already been noted above. As 1:11 is an integral part of the J story, 1:13-14 therefore cannot be. ${ }^{11}$ These verses, however, fit well as the Egyptian response to the fertility of the Israelites recorded by $\mathrm{P}$ in $1: 7$. Further, the harsh labor, ${ }^{a} b \bar{o} d \bar{a}^{h} q \bar{a} s \bar{a}^{h}$, in $1: 14$ is precisely what, according to $P$, the Israelites are said to be suffering from in Exod 6:9. The account of Israel's oppression in 1:13-14 can therefore be attributed to P. ${ }^{12}$

As noted above, the fact that two midwives are sufficient for the entire Israelite community in 1:15 indicates that, contrary to the J and P stories that have preceded, here the Israelites have not yet increased. ${ }^{13}$ This verse thus begins yet a third story in Exodus 1, a story which continues uninterrupted through the end of the chapter. The compositional integrity of these verses is

11) Although some scholars have seen fit to divide Exod 1:13-14 into two sources (P and J) on the basis of its ostensibly repetitive character (cf. Bacon, Triple Tradition, p. 8; Dillmann, Exodus, p. 13; Carpenter and Harford-Battersby, Hexateuch, vol. 2, p. 81; Holzinger, Exodus, p. 1; O. Procksch, Das nordhebräische Sagenbuch die Elohimquelle übersetzt und untersucht [Leipzig, 1906], p. 60; Meyer, Israeliten, p. 41 n. 1; Smend, Erzählung, p. 120; McNeile, Exodus, p. 4; Rudolph, "Elohist," p. 1; Simpson, Early Traditions, p. 158; G. Fohrer, Überlieferung und Geschichte des Exodus: Eine Analyse von Ex 1-15 [BZAW 91; Berlin, 1964], p. 10 [who attributes the non-priestly part to his " $N$ " source]), there is no reason to do so; indeed, removing 1:14a, as has been suggested (Carpenter and Harford-Battersby, Hexateuch, vol. 2, p. 81), creates in P an even more egregiously repetitive text. On the unity of 1:13-14, see Schmidt, Exodus, p. 16.

12) See the scholars cited in n. 2 above, as well as A. Kuenen, An Historico-Critical Inquiry into the Origin and Composition of the Hexateuch (London, 1886), p. 329; M. Noth, Exodus: A Commentary (OTL; Philadelphia, 1962), p. 22; B. S. Childs, The Book of Exodus (OTL; Louisville, 1974), p. 7; C. Levin, Der Jahwist (FRLANT 157; Göttingen, 1993), p. 315; J. Van Seters, The Life of Moses: The Yahwist as Historian in Exodus-Numbers (Louisville, 1994), p. 23; Propp, Exodus 1-18, p. 126; Gertz, Tradition, pp. 353-354; Schmid, Genesis, p. 216. The word baparek in Exod 1:13-14 is known elsewhere only from P, in Lev 25:43, 46, 53. Cassuto (Exodus, pp. 9, 12) notes that the repetition in the description of the Egyptians' oppression of the Israelites in Exod 1:13-14 serves to parallel the repetition in the description of the increase of the Israelites in 1:7 (so too Ackerman, "Literary Context," pp. 83-84).

13) So already Bacon, Triple Tradition, p. 7. Whether the midwives were Egyptian or Israelite is debatable, but not relevant for the source analysis nor, particularly, for the narrative as a whole (for discussion of this issue, see Greenberg, Understanding Exodus, pp. 26-27; C. Houtman, Exodus [3 vols.; HCOT; Kampen, 1993-2000], vol. 1, pp. 251-252). 
highlighted by the repeated use of the word $m^{\partial}$ yall dôt, "midwives," in every verse but two; and those two verses, 1:16 and 1:22, are the two commands of Pharaoh regarding the killing of newborn Israelite boys, the first to the midwives and the second to the populace at large. ${ }^{14}$ Some scholars have argued that 1:20b, "the people multiplied and increased greatly," does not belong to the same source as the surrounding verses. ${ }^{15}$ Yet $1: 20 \mathrm{a}$ does not lead naturally into $1: 21$. The latter verse begins with the rationale for God's rewarding the midwives - "because the midwives feared God" — and then the description of the reward: "he established households for them." The phrase "God dealt well with the midwives" in 1:20a would only make sense coming after the rationale, not before it. Indeed, there may be a common misunderstanding of the contextual sense of 1:20a altogether. It is usually taken as a thought separate from that which follows: "God dealt well with the midwives [i.e., they were rewarded]. The people multiplied and increased greatly [also]." Yet given that the job of the midwives is to safely deliver the Israelite newborns, we may be better served to understand the two clauses as directly related: "God dealt well with the midwives [i.e., they prospered at their task], and [as a result] the

14) Attempts to see 1:22 as belonging to J (cf. Addis, Documents, vol. 1, pp. 107-108; Carpenter and Harford-Battersby, Hexateuch, vol. 2, p. 81; Procksch, Elohimquelle, p. 60; McNeile, Exodus, pp. 5-6; Noth, Exodus, p. 23; Childs, Exodus, p. 7; A. W. Jenks, The Elohist and North Israelite Traditions [SBLMS 22; Missoula, 1977], p. 40; Schmidt, Exodus, p. 21; Propp, Exodus 1-18, p. 142) are predicated on the faulty assumption that both $\mathrm{J}$ and $\mathrm{E}$ must have told essentially the same story; there is no place for 1:22 in J's narrative, nor does it constitute a contradiction to the preceding E narrative-it is, rather, a development thereof (cf. Graupner, Elohist, p. 48; Gertz, Tradition, pp. 373-374, also argues for the continuity of 1:15-21 and 22, though without calling it E, of course). The connection between 1:8-12 and 22 is made also by Schmid (Genesis, p. 216), though he attributes these verses not to $\mathrm{J}$ but to a post-priestly hand (itself then supplemented by $1: 15-21)$.

15) Cf. Wellhausen, Composition, p. 69; Bacon, Triple Tradition, p. 8; Addis, Documents, vol. 1, p. 108; Carpenter and Harford-Battersby, Hexateuch, vol. 2, p. 81; Baentsch, Exodus, p. 8; Procksch, Elohimquelle, p. 60; McNeile, Exodus, p. 5; Driver, Exodus, p. 7; Brightman, Sources, p. 79; Simpson, Early Traditions, p. 158. It is possible, as in P in 1:7, that the word wayya'asm $\hat{u}$ in 1:20 is a secondary addition on the basis of $1: 9(\mathrm{~J})$. The collocation of $r-b-h$ and $-s-m$ occurs elsewhere in $\mathrm{E}$ only in the quite different context of Num 32:1, and it is notable that in both P (Exod 1:7) and E (1:20) the word is added immediately after an original use of $r-b$ - $h$, and that in both it is rendered in the plural; in 1:20, however, we would expect the singular to match wayyireb $h \bar{a}^{-} \bar{a} m$, thus suggesting that the same secondary hand added both occurrences (cf. Schmidt, Exodus, pp. 11-12, 19). We may, however, note the possibility that the words $r-b-h$ and '- $s-m$ were simply traditional elements of the story of the Israelites' expansion in Egypt, and that this tradition accounts for the authentic presence of the phrase in all three sources in Exodus 1 (as, it is clear, $r-b-h$ alone is an authentic part of each source's narrative). 
people multiplied and increased greatly." Reading the text this way allows for the clear distinction between the two thoughts of 1:20 and 1:21: the increase of the Israelite people, and the reward of the midwives. ${ }^{16}$ The repetition of the notice of the Israelites' increase in 1:12 and 20b also argues against the two verses being from the same source. ${ }^{17}$ As this passage is neither $\mathrm{J}$ nor $\mathrm{P}$, it is presumably from E. ${ }^{18}$ This presumption is supported by the presence in this story of a prominent E feature: the midwives do not obey Pharaoh because they fear God, and they are rewarded by God for it $(1: 17,21)$. The fear of God as a mark of faith and obedience is a central theme in E (cf. Gen 20:11;22:12; Exod $18: 21 ; 20: 17) .{ }^{19}$

These three stories all continue into Exodus 2, each following the lines established in Exodus 1. The story of Moses' birth and adoption by Pharaoh's daughter in 2:1-10 is entirely dependent on the immediately preceding E narrative of 1:15-22. ${ }^{20}$ Pharaoh's instructions to kill every newborn Israelite boy

16) Cf. Cassuto, Exodus, p. 15.

17) Cf. Holzinger, Exodus, p. 2. For the view that 1:21 is an addition, see Schmidt, Exodus, pp. 18-20.

18) Cf. Wellhausen, Composition, p. 69; Kuenen, Hexateuch, p. 149; Bacon, Triple Tradition, pp. 7-8; Dillmann, Exodus, pp. 1-2; Carpenter and Harford-Battersby, Hexateuch, vol. 2, p. 81; Holzinger, Exodus, pp. 1-2; Driver, Exodus, pp. 6-7; Brightman, Sources, pp. 156-147; M. Noth, A History of Pentateuchal Traditions (Englewood, 1972), p. 36; Schmidt, Exodus, pp. 21-22; Jenks, Elohist, p. 40.

19) Cf. Jenks, Elohist, p. 40; H. W. Wolff, "The Elohistic Fragments in the Pentateuch", in H. W. Wolff and W. Brueggemann, The Vitality of Old Testament Traditions (2nd ed.; Atlanta, 1982), pp. 67-82; J. Vermeylen, "Les premières étapes littéraires de la formation du Pentateuque", in A. de Pury and T. Römer (eds), Le Pentateuque en Question (3rd ed.; MdB 19; Geneva, 2002), pp. 149-197 (151-160); Graupner, Elohist, pp. 52-55. The other side of fearing God in E is that God regularly comforts humans with the phrase "Fear not" (Gen 15:1; 21:17; 46:3; Num 21:34). We may also note that the divine epithet "the Fear of Isaac" (Gen 32:42, 53), although construed with the root $p-h-d$ rather than $y-r-$ ', is also unique to $\mathrm{E}$.

20) Cf. Wellhausen, Composition, p. 69; Bacon, Triple Tradition, pp. 8-9; Dillmann, Exodus, pp. 1-2; Carpenter and Harford-Battersby, Hexateuch, vol. 2, pp. 81-82; Holzinger, Exodus, p. 5; Baentsch, Exodus, pp. 9-10; McNeile, Exodus, pp. 6-9; Driver, Exodus, pp. 8-12; Brightman, Sources, pp. 147-148; Childs, Exodus, pp. 17-18. This continuity has been described at length by Weber, “ “... Jede Tochter,” and Ina Willi-Plein, "Ort und literarische Funktion der Geburtsgeschichte des Mose", VT 41 (1991), pp. 110-18, although she attributes the passage to J. The structural integrity of these verses has been highlighted by J. C. Exum, " "You Shall Let Every Daughter Live': A Study of Exodus 1.8-2.10”, Semeia 28 (1983), pp. 63-82 (66-67), who points to the use of ben and bat as keywords for the entire section (following Cassuto, Exodus, p. 17; see also Weber, “'... Jede Tochter”, pp. 50-51, 54). The claim of Schmid (Genesis, p. 140) that "Exodus 2:1-10 is readable and understandable by itself, apart from Exodus 1" is difficult to accept; although it may be tradition-historically independent, in literary terms it is the clear 
provide the necessary rationale for Moses' mother hiding him. Pharaoh's daughter's recognition upon finding Moses that "this must be a Hebrew child" (2:6) similarly presupposes those instructions. The presence of Moses' sister in these verses contributes to the identification of the text as E, since it is only in E that Moses has a sister-who will later be referred to by name as Miriam (cf. Exod 15:21-22; Num 12:1-15; 20:1). ${ }^{21}$ Just as in the E story in Exodus 1, here too there is no mention of any labor having yet been imposed on the Israelites.

The story of Moses killing the Egyptian taskmaster and running away to Midian in 2:11-23a , in turn, cannot be from the same source as the verses which precede it in this chapter. ${ }^{22}$ First, the story is dependent on the idea that Pharaoh has indeed imposed forced labor on the Israelites, a notion which, as already mentioned, is nowhere to be found in E's story to this point. Second, if these verses were the continuation of $2: 1-10$, then the question the Israelites ask of Moses in 2:14_ "Who made you chief and ruler over us?" — would be strange indeed: according to 2:10, after all, Moses was raised as the adopted grandson of Pharaoh, and would surely have wielded significant power over the Israelite slaves. ${ }^{23}$ The question in 2:14, therefore, presumes that such is not the case, that Moses has in fact no power over the Israelites. Third, the very first words of 2:11 — "In those days Moses grew up" - make little sense as following directly on the preceding story, in which Moses has just been weaned and brought to Pharaoh's daughter. Most translations render this phrase at the

continuation of the preceding narrative, and removing it from that context would in fact leave Exod 1:15-22 as something of a narrative dead end (a problem that Schmid attempts to solve by attributing Exod 1:15-21 to a later redactional layer [Genesis, 64]; see also Fohrer, Überlieferung, pp. 11-13). The idea that Moses was put in the Nile because he was the product of an illegitimate marriage (Schmid, Genesis, pp. 141-143) is, to my mind, reading too much into the text. Gertz (Tradition, p. 375) puts it nicely: "2,1 markiert einen Szenenwechsel, jedoch kaum einen Wechsel der literarischen Komposition." See also Van Seters, Life, pp. 24-25.

21) These verses also contain, in Exod 2:5, the uniquely E word for female slave, 'ām $\bar{a}$ (cf. Gen $21: 10,12,13 ; 30: 3$; Exod 21:7, 20, 26, 27, 32; 23:12). It is also possible that E later makes reference to Moses' royal upbringing, at least implicitly; in Exod 11:3, we are told that "Moses was much esteemed in the land of Egypt, among Pharaoh's courtiers and among the people." Though this description may have some basis in the E plagues story (now missing from the text), it is also possible that Moses' status was high, particularly among the Egyptians, as a result of his having once been part of the royal household.

22) There are no grounds for separating Exod 2:11-23a $\alpha$ into two stories, one of Moses killing the Egyptian and one of Moses in Midian; each requires the other to make sense in a continuous narrative.

23) Childs (Exodus, p. 31) recognizes this-"Moses must act in secrecy because he has no authority!"- but does not draw the appropriate conclusion therefrom. 
beginning of 2:11, wayhî bayyāmîm hähèm wayyigdal mōš $e^{h}$, as "one day, after Moses had grown up." ${ }^{24}$ This translation is, however, harmonistic. Everywhere else in the Bible, the phrase bayyāmîm hāhèm means "in those days," or "at that time," and modifies the attached verbal clause, rather than the other way around as is implied in the standard translations of Exod 2:11. ${ }^{25}$ It indicates identity of time, not passage of time. Thus we should translate this as "in those days, Moses grew up"; that is, at the same time as what immediately precedes. ${ }^{26}$ It is not sensible to say that at the same time that Moses was a toddler, he grew up. ${ }^{27}$ The story in 2:11-23a $\alpha$ cannot follow 2:1-10 directly, as is indicated by the commonly irregular translation of the standard phrase bayyāmîm hāhēm.

24) As in the ESV, NAB, NIB, NIV, NRSV, and virtually all commentators. Even translations that correctly render the temporal clause as "in those days" continue with "when Moses had grown up" (as in the ASV and KJV). The NJPS translation renders this as "some time after that,

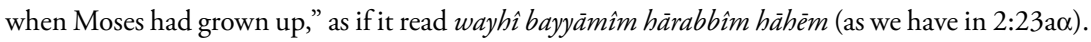
We should probably see the paired phrases at the beginning of 2:11 and 2:23 as part of the J author's intentional style: at that time, Moses grew up (2:11); a long time after that, the king of Egypt died $(2: 23 \mathrm{a} \alpha)$. Reading them as if they meant the same thing obscures this artistic choice on the part of the author.

25) Cf. Gen 6:4; Deut 17:9; 19:17; 26:3; Jos 20:6; Jdg 17:6; 18:1; 20:27, 28; 21:25; 1 Sam 3:1; 28:2 Sam 16:23; 2 Kgs 10:32; 15:37; 20:1; Isa 38:1; Jer 31:29; 33:15, 16; 50:20; Ezek 38:17; Zec 8:6; Est 1:2; 2:21; Dan 10:2; Neh 6:17; 13:23; 2 Chr 32:24. The full temporal clause wayh $\hat{\imath}$ bayyämîm hähèm is used in Jdg 19:1; 1 Sam 28:1. Childs (Exodus, pp. 28-29) correctly observes that "wayyigdal cannot be subordinated to wayyesse as a circumstantial clause, as in the LXX and most modern translations" (p. 28), but does not see this as a source-critical problem. He attempts to see the repetition of the word as part of the author's stylistic means of conjoining the narratives of Exod 2:1-10 and 11-22, yet all the other examples of such repetition he brings come exclusively from within 2:11-22. Cassuto (Exodus, p. 21) recognizes and attempts to avoid the logical contradiction by recourse to two prooftexts, 1 Sam 3:2 and Gen 39:11, neither of which says bayyāmîm hähēm (in fact each uses a different expression).

26) So Baentsch, Exodus, p. 13: "Die Zeitbestimmung hat keine Beziehung; gemeint sind die Tage der Bedrückung, von denen in J unmittelbar vorher die Rede gewesen sein muss." Similarly Schmidt, Exodus, p. 90, though he nevertheless (tentatively) assigns Exod 2:1-10 to J (Exodus, p. 64).

27) The issue here is thus not, as Van Seters (Life, p. 30) suggests, the two distinct meanings of wayyigdal in 2:10 and 2:11 (indeed, a repeated word can have two distinct nuances within even a single verse from a single author, as does wayyěsel in 2:15); it is the temporal discontinuity between the two verses (observed by Levin, Jahwist, p. 321). Gertz (Tradition, pp. 376-377) avoids the problem by ascribing Exod 2:4, 7-10a $\alpha$ to a later addition (following Gressmann, Mose, p. 1 n.1, and Rudolph, "Elohist," p. 4). Similarly, Fohrer (Überlieferung, p. 19) ascribes 2:3b-10a to $\mathrm{E}$; the two resulting narratives in 2:1-10, however, are thereby each left with unaccountable gaps; Fohrer's analysis, like many from the classical period of documentary scholarship, assumes that $J$ and $E$ told the same story in virtually the same way. On the unity of 2:1-10, see Schmidt, Exodus, pp. 51-55; Van Seters, Life, pp. 25-29. 
If 2:11-23a $\alpha$ cannot be E, then it must be either J or P, both of which have introduced the notion that Pharaoh oppressed the Israelites with labor. Numerous elements in the text point to its identification as J. Moses witnesses the labors of his kinsmen, siblotam (2:11)_precisely the word used to describe the oppression of the Israelites in J in $1: 11$, where P uses ${ }^{a} b \bar{o} d \bar{a}^{b}(1: 13-14)$. The notion that Moses went to Midian to escape the authorities is unique to $\mathrm{J}$, and is mentioned again by $\mathrm{J}$ in 4:19 (where the death of Pharaoh, described in 2:23a $\alpha$, is also noted) ${ }^{28}$ in P, Moses does not leave Egypt. In 2:18, Moses' father-in-law is identified as Reuel; this identification is also unique to J (cf. Num 10:29). ${ }^{29}$ And though the meeting at the well may be a literary typescene, it is one that, in the Pentateuch, is present exclusively in the J narrative (cf. Gen 24; 29:1-14). ${ }^{30}$ Thus 2:11-23a $\alpha$ belong to J. ${ }^{31}$ There are some typical $\mathrm{J}$ stylistic features in these verses as well. The collocation of 'is misrî $(2: 11,19)$ and ' $i \hat{s}$ ' $i b r \hat{\imath}$ (2:11) is paralleled in Gen 39:1, 14. In 2:20, the phrase lāma $\bar{a}^{h} z e^{b}$ is found regularly in J (cf. Gen 18:13; 25:22; 33:15; Exod 5:22; 17:3; Num $11: 20 ; 14: 41)$. The construction used for naming Gershom in $2: 22$, wayyiqra $\vec{a} .$. $k \hat{\imath}$ ' $\bar{a} m \bar{a} r$, is found elsewhere only in J (Gen 16:13; 29:32).

28) This connection is drawn by Blum, Komposition, p. 239 n. 40, although of course without ascribing it to $\mathrm{J}$.

29) In E, Moses' father-in-law is named Jethro (cf. Exod 3:1; 4:18; 18:1, 2, 5, 6, 9, 10, 12); in P, there is no mention of Moses even being married.

30) On the type-scene of the well, and in general, cf. R. Alter, The Art of Biblical Narrative (New York, 1981), pp. 47-62. Although A. Rofé has argued that Genesis 24 is a late text ("An Inquiry into the Betrothal of Rebekah," in E. Blum, et al. [eds.], Die Hebräische Bibel und ihre zweifache Nachgeschichte [Neukirchen, 1990], pp. 27-40), the literary connections in this chapter are all to J texts, and not to any non-J material. In Gen 24:7, "Yahweh, the god of heaven, who took me fro my father's house and from my native land," we find a direct reference to Gen 12:1; in the same verse, the phrase "who promised me on oath, "I will assign this land to your offspring" refers to $12: 7$. The oath sworn by placing the hand under the thigh in 24:9 is paralleled in the J text of Gen 47:29. The ancestry of Rebekah, detailed in 24:15, is dependent on Gen 22:20-23, which in turn is dependent on Gen 11:29—indeed, the genealogical notices in the latter two passages are relevant exclusively as the background to the narrative of Genesis 24. The enumeration of Abraham's wealth in 24:35 is nearly identical to that of Gen 12:16. Laban's dismissal of Rebekah uses the phrase qah wälèk, elsewhere in the Bible only in the similar context of Gen 12:19. Isaac is said to come from Beer-lahai-roi, a place only known from J (Gen 16:14), and where, according only to J, Isaac settled permanently (Gen 25:11b). See also the rebuttal of Rofé by G. Rendsburg, "Some False Leads in the Identification of Late Biblical Hebrew Texts: The Cases of Genesis 24 and 1 Samuel 2:27-36”, JBL 121 (2002), pp. 23-46.

31) Cf. Wellhausen, Composition, p. 69; Dillmann, Exodus, p. 2; Baentsch, Exodus, pp. 13-14; McNeile, Exodus, pp. 9-12, 15; Driver, Exodus, pp. 13-16; Brightman, Sources, pp. 79-80; Schmidt, Exodus, pp. 88-89; Propp, Exodus 1-18, pp. 162, 170. 
The final verses of the chapter, 2:23aßb-25, as most have recognized, belong to P. ${ }^{32}$ Here we find the word ' ${ }^{a} b \bar{o} d \bar{a}^{h}$ used to describe the labors of the Israelites, as in P in 1:13-14. The cause-and-effect relationship between God hearing the Israelites cry out and remembering his covenant with the patriarchs in 2:24 is uniquely $\mathrm{P}$ and is recalled by God in 6:5, using the same rare word for "moaning," $n a^{\prime a} q \bar{a}^{h}$. Indeed, the basic idea of God remembering his covenant is exclusively priestly (cf. Gen 9:15, 16; Lev 26:42, 45).

When the narrative contradictions and continuities are taken into account, therefore, Exodus 1-2 can be recognized as the compilation of three distinct narratives, $\mathrm{P}, \mathrm{J}$, and E, each with its peculiar claims as to what happened at the beginning of the Israelites' tenure in Egypt. We may now turn to the examination of each of the stories individually.

\section{The P story: Exod 1:1-5, 7, 13-14; 2:23a $\beta-25$}

We begin with the briefest of the accounts, that of P. The beginning of the priestly account, in Exod 1:1-5, 7, is, in grammatical terms, couched entirely as background information. As all the information contained in these verses is repeated from earlier in $\mathrm{P}$, this is only to be expected. The new information, and thus the main line of the narrative, begins with 1:13-14, the oppression of the Israelites. No explicit rationale for the oppression is provided in $\mathrm{P}$, though it may be understood that the Egyptians were reacting to the spread of the Israelites in 1:7.33 The description of the oppression in 1:13-14 is presented in a typically circular priestly style: the more general description of 1:13 is almost exactly repeated in 1:14b, with the central clause, $1: 14 \mathrm{a}$, providing the details. Though repetitive, this style also serves to emphasize the harshness of the Egyptian oppression, as both 1:13 and 1:14 end with the adverbial $b^{a}$ parrek, "ruthlessly." Similarly, the repetition of the word "a $b \bar{o} d \bar{a}$, "work, labor," in these verses serves to emphasize the coming transition in P from "abodat mișāyim to "aōdat YHWH.

P moves immediately to the Israelites crying to God, and God remembering his covenant with the patriarchs $(2: 23 \mathrm{a} \beta \mathrm{b}-25)$. The brevity with which $\mathrm{P}$ recounts the situation prior to God's intervention-the oppression in 1:13-14 and the crying out of the Israelites in 2:23a $\beta$, after all, cover four hundred years of Israelite enslavement (cf. Exod 12:40)—is typical of P's narrative style

\footnotetext{
32) See the scholars cited in n. 2.

33) It is unnecessary to suppose that $P$ required an explicit rationale equivalent to that of Exod 1:8-12, as argued by Greenberg, Understanding Exodus, p. 65 n. 2.
} 
throughout: long passages of time are moved through very quickly, until the story reaches a moment on which $\mathrm{P}$ expands in great detail (creation, the flood, the covenant with Abraham, the purchase of the cave of Machpelah, etc.). The entire P narrative of Exodus 1-2, therefore, is best seen as the introduction to the main story to come, which begins in earnest in 6:2 with God's speech to Moses-in which the information from these chapters is reused and reconfigured as the rationale for the impending revelation of God's power to both the Egyptians and the Israelites. ${ }^{34}$

It has become relatively common in recent pentateuchal scholarship to claim that the narratives of the patriarchs were originally unconnected with those of the Exodus. To this end it is argued that 1:1-5 serves as a deliberate transition between the two corpora. ${ }^{35}$ Yet this type of repetition, with previously given information presented retrospectively in disjunctive clauses, is in fact typical of $P$ everywhere, as a few examples will demonstrate. ${ }^{36}$ Gen 5:1-2 are a disjunctive reiteration of 1:27-28. Gen 7:13-15 repeat what was said already in 7:7-9*. ${ }^{37}$ Gen 17:26-27 are the disjunctive parallel to 17:23. Exod 11:10 repeats, in brief, the priestly plagues cycle of the preceding chapters. Exod 12:41 repeats the information from 12:37. Exod 14:29 is the disjunctive parallel to 14:22. It is thus a mistake to see in Exod 1:1-5, 7 a marked transition between two previously separate narratives, or a marked juncture in the priestly narrative as a whole. ${ }^{38}$ These verses are no more marked than the many others in $\mathrm{P}$ in which the same technique is used. We need not, therefore, read

34) Cf. Blum, Komposition, pp. 239-241.

35) Cf. Greenberg, Understanding Exodus, pp. 65-66, and Levin, Yahwist, p. 315, for whom Exod 1:1-7 as a whole serve this purpose. Fohrer (Überlieferung, p. 9) saw Exod 1:1-5 as a postredactional insertion intended to bridge the gap between Genesis and Exodus (he is followed by Gertz, Tradition, pp. 354-357; Propp, Exodus 1-18, p. 125). P. Weimar ("Exodus 1,1-2,10 als Eröffnungskomposition des Exodusbuch", in M. Vervenne (ed.), Studies in the Book of Exodus [BETL 126; Leuven, 1996], pp. 179-208) has argued that the entirety of Exod 1:1-2:10 serves this purpose.

36) The phenomenon described here has much in common with the priestly literary technique designated "echo" by S. E. McEvenue, The Narrative Style of the Priestly Writer (AnBib 50; Rome, 1971), p. 38.

37) Gen 7:8a belongs to J, as it refers to the clean and unclean animals (in fulfillment of Yahweh's instructions in J alone, 7:2, and in anticipation of the sacrifices after the flood, also exclusively in J, 8:20).

38) If there is a marked transition here, it is between the literal b’nê yiśräel $l$ in Exod 1:1-i.e., the twelve sons of Jacob—and the figurative $b^{\natural} n \hat{e}$ yiśra $\bar{e} e l$ in 1:7—the Israelites as a national entity. The distinct uses of this phrase in these two verses are not, as some have suggested, an indication of different authorship, but are rather an intentional choice on the part of a single author to effect the transition between the individual and national senses of "Israel." 
the P story in Exodus 1-2 as serving any higher tradition-historical goal; the P narrative is continuous, and level, throughout. ${ }^{39}$

\section{The E story: Exod 1:15-2:10}

The E story is the only one of the three which is presented continuously in the canonical text of Exodus 1-2, comprising 1:15-2:10. As noted above, it begins at a point when the Israelites had not yet dramatically increased; two midwives care for the entire population. Though the Israelites may not have been a very large population, they were evidently sufficient enough in size for Pharaoh to feel threatened by their presence. ${ }^{40}$ Pharaoh's instructions to the midwives to kill the newborn Israelite boys presuppose that the Israelites are subservient to the king; he is clearly in a position of great power over them. This does not, however, necessarily mean that they have been forced into slavery, a notion which is nowhere evident in the $\mathrm{E}$ account. Indeed, according to $\mathrm{E}$ the oppression of the Israelites constitutes nothing other than Pharaoh's attempt to kill the newborn Israelite males. This attempt should not be taken as in any way less oppressive than forced labor; rather, it is more so, since the forced labor of $\mathrm{P}$ and $\mathrm{J}$ is aimed only at population suppression, while the killing of the newborn boys would, if carried out, result in population annihilation after a single generation. The Israelites were not enslaved according to E; they were, rather, nearly exterminated. ${ }^{41}$

\footnotetext{
39) The continuity of the $P$ narrative in Exodus 1-2, for its part, stands as a rebuttal to the claim that $\mathrm{P}$ was not a self-standing document; even Blum admits, "die priesterlichen Stücke Ex 1,15.7; 2:23aß-25; 6,2ff. in dieser Abfolge sich durchaus als fortlaufender Text lesen lassen" (Komposition, p. 240). Blum simultaneously argues, however, that $\mathrm{P}$ was also written in light of the non-priestly material, a judgment based on the absence of a formal introduction of Moses (on which see below). See the response to this claim, with particular regard to Exod 1-2, 6, in L. Schmidt, Studien zur Priesterschrift (BZAW 214; Berlin, 1993), pp. 2-10.

40) This is the case also in J: even in the first generation after Joseph's death, the Israelites are already too numerous for Pharaoh's liking (Exod 1:6, 8-9). We need not read 1:9 as denoting that the Israelites have already increased (so, e.g., Schmid, Genesis, pp. 63-65); indeed, this would, as observed above, make the explicit statement of their increase in 1:12 quite redundant. Rather, 1:9 describes the Egyptian attitude toward the Israelites.

41) Thus we can agree with the fundamental insight of Gressmann (Mose, pp. 1-16) and Childs (Exodus, pp. 10-11), that there were separate traditions regarding the threat to the Israelites in Egypt: one of slavery and one of, as Childs puts it, "genocide." The source analysis presented here keeps these two traditions in separate sources, however, rather than seeing them as combined at a pre-literary stage into a single narrative.
} 
Reference to the enslavement of the Israelites is strikingly absent from $\mathrm{E}$ in its subsequent mentions of the Exodus. E uses the root $l-h-s$ to describe the oppression of the Egyptians in Exod 3:9; this root does not in itself carry any connotation of physical enslavement or labor, but rather means simply to mistreat. This meaning is clear from the two other uses of the root in E, both of which are also in the context of the Exodus, Exod 22:20 and 23:9, in the Covenant Code laws about treatment of gèrîm: "you shall not $l-h-\underline{s}$ the gèr, for you were gêrîm in Egypt." The Israelites are instructed here to refrain not from enslaving the resident alien, but rather from mistreating him. ${ }^{42}$ Strikingly, E does not use the equivalent language when giving laws about slavery; there is no statement "for you were slaves in Egypt." By contrast, in the slave laws of Deuteronomy, this is precisely what is said (Deut 15:15), and elsewhere in Deuteronomy the fact of Israel having been enslaved is used as justification for various laws (cf. Deut 16:12; 24:18, 22). Similarly, the laws regarding debtslaves in Lev 25:39-46 are determined in part by recollection of Israel's enslavement in Egypt (25:42). There is no equivalent to these passages in E. It is often conjectured that the placement of the slave law at the beginning of the Covenant Code, a placement which has no parallel in other Israelite or ANE law collections, is based on the preceding narrative of Israel's deliverance from slavery. ${ }^{43}$ Yet if there was no slavery in E, this explanation can no longer hold, and alternatives must be sought. ${ }^{44}$

The one phrase in an E context that does seem to reflect a tradition of Israelite enslavement in Egypt is the reference to Egypt as a bêt "áadim in the Decalogue (Exod 20:2). Yet there is good reason to think that this phrase is not original to E's Decalogue. Elsewhere in the Pentateuch, the phrase occurs primarily in D (Deut 5:6; 6:12; 7:8; 8:14; 13:6; 13:11), and in Exod 13:3, 14, which is a late addition to the Pentateuch. ${ }^{45}$ It is not surprising that a $D$

42) See J. Reindl, "lāhass," TDOT, vol. 6, pp. 529-533 (532): "lāhạ aims at antisocial exploitation of the ger's inferior legal position."

43) Cf., e.g., S. M. Paul, Studies in the Book of the Covenant in the Light of Cuneiform and Biblical Law (Leiden, 1970), p. 52; L. Schwienhorst-Schönberger, Das Bundesbuch (Ex 20,22-23,33) (Berlin, 1990), p. 313; N. Sarna, The JPS Torah Commentary: Exodus (Philadelphia, 1991), p. 118; Cassuto, Exodus, p. 266; W. H. C. Propp, Exodus 19-40 (AB 2A; New York, 2006), p. 188.

44) A recent possibility is that offered by D. P. Wright, Inventing God's Law: How the Covenant Code of the Bible Used and Revised the Laws of Hammurabi (Oxford, 2009), pp. 149-51; Wright argues that the Covenant Code begins with the laws of debt-slavery because the entire law collection has a thematic focus on poverty.

45) Cf. S. Gesundheit, "Three Times a Year" (FAT; Tübingen, forthcoming), pp. 181-239. I thank Prof. Gesundheit for providing me an advance look at the manuscript. 
element should have made its way into the E Decalogue; there is good evidence that the Decalogue was a particularly well worked-over text (note the redactional insertion of P elements in Exod 20:11), and it has been suggested that the final form of the two Decalogues in Exodus 20 and Deuteronomy 5 is the result of a boomerang effect, with each version affecting the redaction of the other. ${ }^{46}$ It is, of course, also possible that the phrase was inserted by a scribe who knew it from Deuteronomy 5 and either accidentally or intentionally copied it here. The reference to the bêt " ${ }^{\text {ba }}$ dìm in Exod 20:2 should not, therefore, affect the argument presented here.

There is, then, no enslavement of the Israelites either in the E narrative of Exodus 1-2 or anywhere else in the larger E document. Recognition of this aspect of E's presentation of the oppression in Egypt illuminates the rest of the E story in Exodus 1-2.

The increase of the Israelites in 1:20 ostensibly takes place within a single generation: a baby boom of sorts. ${ }^{47}$ This is indicated by the fact that the increase of the Israelites is dependent on God dealing well with midwives, i.e., giving them success at their appointed task of delivering the Israelite newborns. Thus these two midwives supervised the expansion of the Israelite population, in direct response to Pharaoh's edict to the contrary. The midwives are rewarded in 1:21 for their fear of God with enduring lines of descendants. ${ }^{48}$ This is best taken as proleptic; that is, God bestows on them now a reward that will come to fruition only in future generations. The reward is a promise of future endurance of their family lines. When the midwives fail to follow Pharaoh's instructions (1:17), he imposes the rule on the entire population (1:22). This should probably be taken to mean that it was no longer the midwives' responsibility to kill the newborn males, but in fact that of the Israelite parents themselves. This understanding accounts for the statement of 2:2, that Moses' mother herself made the decision to hide him.

There is no indication in the text that the events of 2:1-10 took place any great length of time after Pharaoh's edict of 1:22. There is no reason to think that the Pharaoh of 1:15 is not the same Pharaoh whose daughter finds Moses

\footnotetext{
46) So already Kuenen, Hexateuch, pp. 166-167; Carpenter and Harford-Battersby, Hexateuch, vol. 2, p. 111.

47) This is the case also according to $P$, in which the Israelites increase when they arrive in Egypt, during Jacob's lifetime (Gen 47:11, 27b-28).

48) The phrase "to establish a house," 'ásis $\bar{a}^{b}$ bayit, means to grant an enduring family line; it is the same phrase that is used for the establishment of the Davidic dynasty (cf. 1 Sam 25:28; 2 Sam 7:11). Greenberg (Understanding Exodus, p. 31) also notes a similar concept in Ruth 4:11. See further Houtman, Exodus, pp. 259-260.
} 
in 2:5. Thus it seems that, according to E, there was but one generation between Pharaoh's edict (and the resulting increase of the Israelites) and Moses' adulthood (and the resulting Exodus of the Israelites). And this is eminently logical, since, as noted above, if Pharaoh's edict were carried out completely, the Israelite population, deprived of any males, would collapse within a single generation. Moses could not be born any later than the same generation as that first affected by Pharaoh's edict. Yet this was not the sole generation of Israelites to dwell in Egypt. According to E, in Gen 50:23, "Joseph lived to see children of the third generation of Ephraim; the children of Machir son of Manasseh were likewise born upon Joseph's knees." Thus after Joseph came to Egypt, and subsequently Jacob and his family, the Israelites lived there for quite some time-three full generations-before the events of Exodus 1-2 took place.

This reading, which assumes that Gen 50:23-26 and Exod 1:15-2:10 were continuous in the original $\mathrm{E}$ narrative, may help to explain the sudden edict of Pharaoh in Exod 1:16. As long as Joseph was alive, the kings of Egypt - and given Joseph's long life, it is certainly reasonable to assume that there was more than one-were obligated to him, and by extension his family, for the services he had rendered Egypt and Pharaoh in Gen 41. After Joseph's death, however, there was no further obligation to his descendants; they were no more than a gradually growing foreign people within Egypt's borders. ${ }^{49}$ Thus it was upon Joseph's death in Gen 50:26 that Pharaoh ordered the midwives to kill the newborn Israelite boys. ${ }^{50}$

If the $\mathrm{E}$ text is to be read consecutively from the end of Genesis through Exodus 1-2, then Moses' birth marks the fourth generation of Israelites to be born in Egypt. Ephraim and Manasseh, Joseph's sons, are the first (Gen 41:5152); Machir, Manasseh's son, is the second (50:23); Machir's children are the third (50:23). We may assume that the same changing of generations took place for all of Joseph's brothers as well: by the time that Machir's children,

49) Cf. Greenberg, Understanding Exodus, p. 22: “At Joseph's death, it appeared that only an act of God would enable the family to leave Egypt. If Pharaoh had any claim over the Israelites other than the mere fact of their residence in his land, it is not stated.... Whatever special favor they may have enjoyed ended as the memory of Joseph faded; only their status of aliens under royal authority remained." (Cf. also Houtman, Exodus, p. 222.) It may be noted in this regard that in E, though Pharaoh put Joseph in charge of Egypt (Gen 41:41-44), there is no description of Pharaoh also welcoming Jacob's family, or promising to provide for them, as there is in J (45:1720) and $P(47: 5-6 a)$.

50) We therefore need not postulate a gap in $\mathrm{E}$ here, to be filled with something equivalent to what is found in J, as suggested by Propp, Exodus 1-18, p. 138. 
Joseph's great-grandchildren, are born, so too are Reuben's great-grandchildren, Simeon's great-grandchildren, et al.—and, most importantly, Levi's great-grandchildren. These would be, according to Exod 2:1, Moses' parents. Thus Moses represents the fourth generation, the last to be born in Egypt, the ones who will be leaving during the Exodus. When this generational scheme in $\mathrm{E}$ is understood, it is also to be recognized that it represents, remarkably, the precise fulfillment of God's prediction in Gen 15:16: "They shall return here in the fourth generation." ${ }^{51}$

Indeed, when the connection between Genesis 15 and the $\mathrm{E}$ account in the end of Genesis and beginning of Exodus is recognized, other plot elements can be more easily understood. At the end of Genesis 50, Joseph tells his brothers before he dies that "God will surely take notice of you and bring you up from this land" (50:24). Even reading canonically, but also within E alone, this statement is confusing: the famine in Egypt has long since ended, and no Pharaoh has yet oppressed the Israelites; why do they not simply return to Canaan? Why must they wait for God to bring them out? When this is read in light of Gen 15:16, however, it makes sense: they cannot leave because they have not yet been there for four generations, as God said they would. But in the fourth generation, precisely, the Israelites do return. This scheme also dovetails beautifully with another narrative feature unique to $\mathrm{E}$ : in $\mathrm{E}$, the

51) Genesis 15 has long been a focal point of source-critical dispute; yet the connections between elements of this chapter and other E passages are numerous, beyond those discussed in this paper. In terms of narrative claims, the statement that the Israelites will leave Egypt with great wealth (15:14) refers to the despoiling of the Egyptians in E (Exod 3:21-22; 11:2-3; 12:35-36). In terms of theme and language, we may note the prophetic address to Abraham in 15:1 (see the depiction of Abraham as a prophet in Gen 20:7, 17); the appearance of God in a vision; the linking of the promise with a reference to the oppression in and Exodus from Egypt (15:13-16; see Gen 46:3-4); the self-identification of Yahweh in 15:7, which is strikingly parallel to that of the Decalogue in Exod 20:2; the description of Yahweh as appearing in smoke and fire in 15:17, as in Exod 20:18 - the only two pentateuchal texts in which the rare word lappîd appears; and the presence of a formal ceremony to mark the making of a covenant, elsewhere only in E (Exod 24:3-8). The attribution of Genesis 15 in its entirety to $\mathrm{E}$ has been made, albeit briefly, by M. Haran, "The Berrit 'Covenant': Its Nature and Ceremonial Background," in Mordechai Cogan, et al. (eds.), Tehillah le-Moshe (Winona Lake, 1997), pp. 203-19 (206 n. 6).

For the argument in this paper, the statement in Gen 15:13b that Abraham's descendants would be enslaved and oppressed in Egypt for four hundred years presents a difficulty, for four hundred years does not equate well to four generations. Yet this difficulty exists in any analysis of Genesis 15 , as has long been recognized. It is perhaps best to take 15:13a $\beta-14 \mathrm{a}$ as redactional: the four hundred years reflects P's claim in Exod 12:40 that the Israelites were in Egypt for 430 years; the use of the verb ' $-b-d$ is taken from $P$ in Exod 1:13-14; the verb $-n-b$ from J in Exod 1:8-12. 
Israelites do not wander in the desert for forty years; the generation that leaves Egypt is the same generation that is to enter Canaan. ${ }^{52}$

E's depiction of Israel's stay in Egypt from Joseph to the generation of Moses is thus relatively clear. Joseph and his family, for generations, were foreigners living in Egypt - as God said they would be: "Know well that your offspring will be strangers ( $g \bar{e} r)$ in a land not theirs" (Gen 15:13a). They stayed in Egypt not because they were oppressed there-yet-but because they had to wait for the fourth generation before they could return, before God could bring them back. After Joseph's death, the Egyptian king was no longer obligated to this intrusive people, and oppressed them-in fact attempted to destroy themby ordering that they kill their newborn sons. Thus the oppression of the Israelites and the rise of the fourth generation, the generation of Moses, coincided; the conclusion of the preordained period of the Israelite stay in Egypt and the truly pressing need for immediate deliverance from Egypt came together to justify in multiple ways the imminent Exodus.

The E story in Exod 1:15-2:10, which stands out from its canonical context and which is somewhat difficult to understand when read in isolation, is made far more sensible when it is seen as integrally connected to other E texts and the narrative claims made therein. That this is the case speaks to the considerable internal coherence of the E narrative, and particularly to the direct continuity of the E story from Genesis into Exodus. Only when that continuity is recognized, and situated in the broader E context going back to Genesis 15, can we fully appreciate the nuances of Exod 1:15-2:10.

\section{The J story: Exod 1:6, 8-12; 2:11-23aa}

Unlike in $\mathrm{P}$ and $\mathrm{E}$, in $\mathrm{J}$ there is no question of the direct continuity of Exod 1:6 with what precedes it in the J narrative. As noted above, Exod 1:6 is the second half of a single sentence beginning in Gen 50:22b. Exod 1:8 makes explicit reference to the preceding account of Joseph: "A new king arose over Egypt who did not know Joseph." As in the E story, the Pharaoh's obligation to Joseph and his family ends after Joseph is no longer alive. And, as in E, even the relatively limited number of Israelites in Egypt in the immediate

\footnotetext{
52) The story in which the Israelites are condemned to wander in the desert until the Exodus generation has died is the episode of the spies in Numbers 13-14. These chapters are composite, but include only $\mathrm{J}$ and $\mathrm{P}$ (for the source division of these chapters, see J. S. Baden, J, E, and the Redaction of the Pentateuch [FAT 68; Tübingen, 2009], pp. 114-118); E has no equivalent story of the Israelites having to wander for any length of time.
} 
post-Joseph generations, before they have increased, is too large for Pharaoh's comfort: "The Israelite people are much too numerous for us" (1:9). ${ }^{53} \mathrm{~J}$ is, however, explicit about the use of forced labor as a means of population control $(1: 10)$. One may have the impression from the universal translation of $1: 12$, "the more they were oppressed, the more they increased," that the oppression and simultaneous increase of the Israelites took place over a significant period of time - that the Egyptians progressively increased their oppression of the Israelites, and similarly that the Israelites progressively increased in number. Yet this translation, which is rooted in a canonical reading, is misleading. Nowhere else does the pair $k a^{n}$ šer... kèn indicate progressive action (and nowhere else is it translated as such). It is simply a means of equal comparison: as $\mathrm{x}$, so $\mathrm{y}$. In this case, we should understand the verse to mean "as much as they oppressed them [i.e., when the Egyptians instituted the labor in the first place], so they increased"; the comparison is in the intensity of the acts described, without any temporally progressive sense. In this J agrees with both $\mathrm{P}$ and $\mathrm{E}$ : the increase of the Israelites took place in a single generation (in the case of $\mathrm{J}$, in the generation that is forced into labor).

The second J section in Exodus 1-2, the story in 2:11-23a $\alpha$ of Moses killing the Egyptian, fleeing to Midian, and getting married there, is a perfectly straightforward narrative that requires little in the way of further explanation on its own terms. What has been less clear, and has in fact been largely obscured in most translations and treatments of this passage, is the transition between 1:8-12 and 2:11-23a $\alpha$. As argued above, the beginning of 2:11 should be translated "in those days, Moses grew up," in accord with the otherwise universal meaning of bayyamîm hähèm. We saw above that this verse cannot follow directly on what precedes it in the E story in 2:10; the question is whether it can follow directly on what precedes it in the J story.

Indeed, the continuity of 1:11-12 to 2:11 makes perfect sense. The Egyptians oppressed the Israelites with forced labor, and the Israelites increased (1:11-12); in those days, Moses grew up (2:11). The latter verse thus explains that Moses came of age in the generation that experienced the Egyptian oppression, as is only logical. The verse also serves as the introduction to the character of Moses in J. It should not be deemed problematic that Moses is not provided with a fuller introduction, birth story, or genealogy. First, it is reasonable to assume that the figure of Moses was well enough known to the

\footnotetext{
53) Rather than "the Israelite people are more numerous than us," which makes little sense either in the context of the J narrative or in any remotely realistic scenario; cf. A. B. Ehrlich, Miqra ki-peshuto (3 vols.; New York, 1969), vol. 1, p. 134.
} 
Israelite audience that a formal introduction would not be necessary; $\mathrm{P}$ also first refers to Moses without any formal introduction in 6:2 (although Moses' genealogy is provided thereafter, in 6:16-27). ${ }^{54}$ Second, Moses' background is of no import in the J story; his unique status among the Israelites is marked in the narrative not by his birth, but by his actions in 2:11-12.55 Unlike Isaac, Jacob, and Jacob's sons, Moses' lineage has no special meaning; he is not the designated inheritor of Yahweh's promise as the patriarchs are. Furthermore, it would be quite unusual were J to give any information about Moses' genealogy or tribal affiliation, as E and P do. After the death of Joseph in Exod 1:6, the individual Israelite tribes are never again mentioned in J; Israel is always a single corporate entity. ${ }^{56}$ Third, there is simply no requirement that every biblical character be formally introduced-consider, for example, Joshua, who appears first and with no fanfare in Exod 17:9. A formal introduction may be a desideratum from our perspective, but it is not a failing of the biblical author.

The reading espoused here also affects our understanding of the verb wayyesese, "he went out," in 2:11. Canonically, this verb suggests that Moses left Pharaoh's palace, where he was raised, to observe the Israelites being oppressed. When the continuity between 2:1-10 and 2:11-23a $\alpha$ is called into question, it is natural to then wonder as to where Moses goes out from in 2:11. Yet it is only with the canonical reading in mind that such a question is pressing. The verb wayyẹs $\vec{e}$ is used elsewhere in the Bible without an explicitly stated previous location, or with the unstated assumption that the character is going out from his dwelling. ${ }^{57}$ In this case, we may similarly assume that when Moses

\footnotetext{
54) Though the absence of a formal introduction in $P$ has been taken as an indication that the priestly narrative is a secondary addition to the pre-existing non-priestly text; cf. Blum, Komposition, pp. 240-241.

55) Cf. Cassuto, Exodus, p. 22.

56) In $\mathrm{P}$, of course, the tribes are regularly referred to (cf., e.g., Exod 6:14-25; 31:1, 6; Num 1-4, $7 ; 10: 13-27 ; 13: 1-15 ; 16: 1 ; 17: 17-25 ; 25: 14 ; 26: 3-59 ; 27: 1 ; 32: 2 ; 34: 14-28 ; 36: 10-12)$. In E tribes are also mentioned, though far more rarely, in two of the main E narratives: Num 16, in which Dathan and Abiram are Reubenites, and Num 32, which features the Reubenites and the Gadites (it may be no coincidence that the Reubenites are the prominently featured tribe in E). We may speculate that the lack of tribal references in J, the emphasis on the Israelite community as a single entity, has some political meaning to it: if, as is frequently suggested, J was written in part or in whole with a pro-united monarchy agenda, then we can imagine that describing Israel as a single entity, rather than as a collective of independent tribes, contributed to such a cause.

57) Cf., e.g., in Genesis-2 Kings, Gen 14:17; 24:63; 34:6; Exod 18:7; Lev 24:10; Num 11:24; 22:36; Judg 9:42; 1 Sam 13:10; 1 Sam 20:35; 2 Sam 24:20; 1 Kgs 2:46; 20:33; 22:21; 2 Kgs 2:21; 4:18; 4:39; 10:9; 19:35.
} 
goes out, he is going out from his home. We should connect this with the preceding clause, "Moses grew up," and understand that what we are being told about is the first time that Moses was old enough to join his fellow Israelites in their labors; he came of age to work. ${ }^{58}$ In this light, the subsequent clause, "he saw their labors," takes on an added meaning: Moses, before this a child, now realized how severely his kindred were being oppressed. The subsequent narrative of killing the Egyptian can then be read as Moses' instinctive reaction to his first visual encounter with the oppression. Similarly, in this light the words 'el-'ehāyw, "to his kinsmen," no longer have the added freight they take on in the canonical text. When 2:11 is read as continuous with 2:110, "his kinsmen" signals Moses' newfound identification with his people, an identification which had presumably been concealed while he was being raised in the Egyptian court. In the context of the J story alone, however, it signals nothing more than that Moses joined his fellow Israelites, for the first time, in participating in their forced labor.

As noted above, the Israelite's question to Moses in 2:14_ "Who made you chief and ruler over us?"-makes better sense if Moses is simply a regular Israelite, rather than Pharaoh's grandson. The same is true of Pharaoh's attempt to kill Moses in 2:15. If Moses were a member of Pharaoh's household, even of his family, then this episode would be a story of treason. When it is recognized that Moses is a regular Israelite, however, then it is a story of rebellion, and foreshadows the entire Exodus narrative in J. ${ }^{59}$

Perhaps the most significant ramification of the analysis of the J story presented here has to do with the time the Israelites spent in Egypt. As we have seen, there is some discrepancy among the sources in this regard: according to $\mathrm{P}$, the period of Israelite enslavement lasted 430 years; according to E, the Israelites were gêrim in Egypt for four generations. If the J story does in fact read continuously from $1: 8-12$ to 2:11-23a $\alpha$, then Moses comes of age in the same generation that the Egyptian oppression of the Israelites begins, and

58) A fine parallel to Exod 2:11 is found in 2 Kgs 4:18: wayyigdal hayyāled wayhî hayyôm wayyêsề 'el-'äbîw 'el-haqqōs? rîm, "The child grew up; one day, he went out to his father among the reapers." Although in the story in 2 Kings the boy is still relatively young, this verse still tells us that he was old enough to join his father in the fields.

59) It should not be taken as significant that Reuel's daughters refer to Moses as an Egyptian in 2:19; this does not mean that this story is to be linked with 2:1-10. After all, Moses came from Egypt to Midian, and would therefore naturally be assumed to be an Egyptian, rather than an Israelite slave (if the Midianites even knew anything about the enslavement of the Israelites in Egypt). 
in which the Israelites increase dramatically: in the generation immediately after the death of Joseph and his brothers (1:6). According to J, therefore, the Israelites are not enslaved for any particularly long time; merely a single generation. Although this may be canonically difficult, within the J story itself it is perfectly acceptable, for unlike $\mathrm{P}$ and $\mathrm{E}$, J never provides a set time for the Israelite stay in Egypt, and never refers to it as a significantly long period. In J, the Israelites are enslaved for a single generation, the generation of Moses, who will lead the Israelites out of Egypt.

\section{Conclusion}

The source division of Exodus 1-2 presented above both solves the contradictions and discontinuities in the canonical text and results in three complete, coherent narratives, each with distinctive claims about the time between Joseph and Moses. Two categories of such claims are particularly noteworthy, as they bring to the forefront divergences among the sources on fundamental aspects of the Exodus story. First, the timing and nature of the Egyptian oppression of the Israelites is different in each narrative strand. According to $\mathrm{P}$, the Israelites increased during the lifetime of Jacob, and were only subsequently oppressed. According to E, the Israelites increased only after Pharaoh had imposed his edict requiring the death of all newborn Israelite boys, and this edict seems to have constituted the oppression proper; there is no forced labor in E. According to J, the Israelites increase in tandem with their oppression, the forced labor which was supposed to keep the Israelites from multiplying. It is clear that the concept of the oppression of the Israelites is a key one for any Exodus story-after all, they need to be freed from somethingbut the details of what the oppression was and when and how it occurred could vary from source to source.

Second, the amount of time the Israelites are said to have spent in Egypt varies from story to story. In P, the Israelites spent 430 years in Egypt (although this significant passage of time is not explicit in Exodus 1-2). In E, the Israelites spent four generations, from the birth of Joseph's sons to the birth of Moses. In J, the Israelites spent but a single generation, from Joseph to Moses, before the Exodus. These variations provide evidence that there was not a common Israelite conception of the length of the stay in Egypt ${ }^{60}$ Nor, for that

\footnotetext{
${ }^{60)}$ It should be noted that regardless of the length of time assigned to the stay, this period is in all cases told exceptionally briefly—only in Exodus 1-2. It takes but two chapters for all three
} 
matter, should we expect there to have been; the true commonalities among the pentateuchal sources are restricted to the most general of historical outlines, while virtually every detail of every common story or episode differs, often substantially, from source to source. The narratives in Exodus 1-2 are no exception.

There are, however, commonalities among the sources in content and form that must be recognized, beyond simply the fact that the Israelites dwelt in Egypt, were oppressed there, and were freed in the time of Moses. In all three sources, the increase of the Israelites is a central feature of the narrative. This increase is more than simply a prerequisite for the existence of a people Israel in what follows; it is also the direct fulfillment of part of the patriarchal promise in Genesis. ${ }^{61}$ The promise is the dominating motif in all three sources in Genesis, and it comprises two elements: progeny and land. ${ }^{62}$ The land aspect of the promise is, of course, not fulfilled until after Moses' death. All the sources agree, however, that the progeny aspect is fulfilled before Moses; after all, Moses leads the entire Israelite people through the wilderness, and it is this same people that is going to take possession of the land. Naturally, then, the progeny aspect of the promise must be fulfilled before Moses leads the Israelites out of Egypt. Thus in P, the promise of progeny given in Gen 17:6; 28:3; $35: 11 ; 48: 4$ is fulfilled in Gen $47: 27$ and Exod $1: 7 ;^{63}$ in E, the promise of progeny given in Gen 15:5; 46:3 is fulfilled in Exod 1:20; in J, the promise of

sources to describe the situation up to Moses, which lasts, depending on the source, from a single generation to over four hundred years; it takes ten chapters for the same sources to describe the Exodus, which takes a month at most.

61) Cf. Greenberg, Understanding Exodus, pp. 35-36.

62) Contrary to some scholars, particularly those writing from a tradition-critical perspective (cf.

C. Westermann, The Promises to the Fathers: Studies on the Patriarchal Narratives [Philadelphia, 1980], pp. 95-163; R. Rendtorff, The Problem of the Process of Transmission in the Pentateuch [JSOTSup 89; Sheffield, 1977], pp. 55-74), the promises of land and progeny are not two separate promises, but two aspects of a single promise. Land and progeny are the twin aspects of God's blessing (which is also not a separate promise): God blesses the patriarchs, which means nothing other than that they will acquire land and progeny. In J, this is clear in association of the general statement of Gen 12:2 and its specific application in Gen 13:14-17, as well as in more immediate connection in Gen 26:3-4; in P, in Gen 28:3-4; 35:10-12; 48:3-4. These two elements also explain what it means to be "a great nation": one that is populous and has a territory to hold that population.

63) Rendtorff's claim (Problem, pp. 84-85) that Exod 1:7 makes "no reference at all to the constantly repeated promise of increase to the fathers" both ignores the repetition here of Gen 47:27 and assumes that references must be remarkably explicit; in fact, a reference to the promise here would be remarkable, insofar as every reference to the patriarchal promises in the entire Pentateuch comes in the form of direct speech, not narrative. 
progeny given in Gen $12: 2 ; 13: 16 ; 18: 18 ; 26: 4,24 ; 28: 14 ; 32: 13$ is fulfilled in Exod 1:12. The best evidence that, for all three sources, the notice of increase in Exodus 1-2 constitutes the fulfillment of the progeny aspect of the patriarchal promises can be seen in the fact that from this point forward, when the promises are referred to-in all the sources - only the aspect of land is mentioned, for it is the only aspect still pending. ${ }^{64}$

That the narratives in Exodus 1-2 record the fulfillment of part of the patriarchal promises from Genesis helps to demonstrate that there is coherence within each of the sources across the Genesis-Exodus boundary. The analysis above, however, goes further than that: there is not only coherence, there is in fact direct continuity in $\mathrm{P}, \mathrm{E}$, and $\mathrm{J}$ from the end of Genesis to the beginning of Exodus, in opposition to Schmid's strong assertion that "in none of the three sources, J, E, or P, does the context between Genesis 50 and Exodus 1 remain intact." ${ }^{65}$ For the $\mathrm{P}$ story this has never been in doubt; for the nonpriestly narratives, however, it has been a common claim in recent scholarship that the Genesis and Exodus texts were originally independent works. ${ }^{66}$ Yet as

64) Cf. Exod 6:4, 8; 13:5, 11; 33:1; Num 11:12; 14:16, 23, 30; 32:11; Deut 31:23; 34:4. The sole exception is Exod 32:13, in which Moses reminds God of the full promise, including both land and progeny. Here, however, the reference to the promise of progeny is demanded by the context, since God has just threatened to destroy the entire Israelite people. It is no coincidence in this light that all of the references to the promise in $\mathrm{D}$-long after the promise of progeny has been fulfilled — mention only the aspect of the land (cf. Deut 1:8, 35; 4:37-38; 6:10, 18, 23; 7:8; $8: 1 ; 9: 5,28 ; 10: 11 ; 11: 9,21 ; 19: 8 ; 26: 3 ; 28: 11 ; 30: 20 ; 31: 7,20)$. It is not that $\mathrm{D}$ does not know of the promise of progeny, or that the aspect of progeny was a later development in the tradition; D's references to the promise are entirely appropriate to their context in the story.

65) Schmid, Genesis, p. 139.

66) So Rendtorff, Problem, pp. 84-89; Schmid, "The So-Called Yahwist and the Literary Gap Between Genesis and Exodus", in T. B. Dozeman and K. Schmid (eds.), A Farewell to the Yahwist? The Composition of the Pentateuch in Recent European Research (SBLSymp 34; Atlanta, 2006), pp. 29-50 (31-34); Gertz, "The Transition Between the Books of Genesis and Exodus", in T. B. Dozeman and K. Schmid (eds.), A Farewell to the Yahwist? The Composition of the Pentateuch in Recent European Research (SBLSymp 34; Atlanta, 2006), pp. 73-87; Blum, "The Literary Connection between the Books of Genesis and Exodus and the End of the Book of Joshua", in T. B. Dozeman and K. Schmid (eds.), A Farewell to the Yahwist? The Composition of the Pentateuch in Recent European Research (SBLSymp 34; Atlanta, 2006), pp. 89-106; idem, "Die literarische Verbindung von Erzvätern und Exodus. Ein Gespräch mit neueren Endredaktionshypothesen," in J. C. Gertz, et al. (eds.), Abschied vom Jahwisten: Die Komposition des Hexateuch in der jüngesten Diskussion (BZAW 315; Berlin, 2002), pp. 119-56. In these two works Blum reverses his earlier position (Komposition, 102-3), in which he viewed Exod 1:6, 8 as the continuation into Exodus of a pre-priestly composition in Genesis, seeing these verses instead as post-redactional, following Gertz and Schmid (see n. 6 above). Most extensively see Schmid, Genesis. 
demonstrated above, the narratives in Exodus 1-2 are fully comprehensible only when they are read as continuous with the preceding stories, both at the end of Genesis and elsewhere therein. In short, there is no Genesis-Exodus boundary; all three sources are continuous from the end of Genesis into the beginning of Exodus. 